\title{
Defoliation and dieback of Sitka spruce in Reykjavík, Iceland
}

\author{
Juliane Kuckuk ${ }^{a}$, Sibren van Manen ${ }^{\mathrm{B}}$, Ólafur Eggertsson ${ }^{\mathrm{c}}$, \\ EdDa Sigurdís OdDSDótTIR ${ }^{c}, \mathbf{J}_{A N}$ ESPER $^{\wedge}$ \\ ${ }^{a}$ Department of Geography, Johannes Gutenberg University, 55128 Mainz, Germany \\ (juliane.kuckuk@gmx.net,esper@uni-mainz.de) \\ ${ }^{b}$ Department of Applied Biology, HAS University of Applied Sciences, 5223 DE s-Hertogenbosch, the Netherlands \\ (s.vManen@student.has.nl) \\ ${ }^{c}$ Icelandic Forest Research Mógilsá, IS-162Reykjavik, Iceland (olie@skogur.is, edda@skoguris)
}

\begin{abstract}
The green spruce aphid Elatobium abietinum is an important defoliating pest of Sitka spruce (Picea sitchensis) in Iceland. A comparison of two urban Sitka stands in Reykjavík, from 2013-2017, reveals a distinct defoliation difference between trees located near a main road (94\% defoliated) and several hundred meters away from heavy traffic (47\%). Chemical analyses of the spruce needles demonstrate substantially higher nitrogen ratios in trees near traffic. Furthermore, the recently warming winter temperatures promoted larger overwintering aphid populations since 2003, as well as a shift of mass outbreaks from autumn to spring, accompanied by distinct growth suppressions one year after an aphid population spike in the post-2003 tree-ring data. The results of this study indicate that the mechanisms triggering Sitka spruce dieback in Reykjavík include a combination of increasing winter temperatures, more frequent and severe green spruce aphid outbreaks, as well as elevated $\mathrm{N}$ values in the needles of urban trees.
\end{abstract}

Keywords: climate change, dendrochronology, green spruce aphids, Picea sitchensis, traffic pollution, treerings

\section{YFIRLIT}

Skemmdir á sitkagreni i Reykjavík af völdum sitkalúsar

Sitkalús (Elatobium abietinum) veldur oft talsverðum skemmdum á sitkagreni (Picea sitchensis) á Íslandi. Samanburður á sitkagrenireitum í Reykjavík, frá 2013 til 2017, leiðir í ljós afgerandi mun á skemmdum vegna sitkalúsar í nánd við fjölfarnar götur (94\% skemmdarhlutfall) og trjáa í nokkur hundruð metra fjarlægð frá umferðaræðum (47\%). Efnagreiningar á barri sitkagrenisins sýna einnig umtalsvert hærra hlutfall köfnunarefnis í trjám nálægt fjölförnum götum. Einnig hefur hækkun vetrarhita síðustu ára (frá 2003) valdið pví að stærri stofnar lúsarinnar lifa af veturinn og fært sitkalúsarfaraldra frá hausti til vors. Pegar vöxtur trjánna er skoðaður sjást greinileg neikvæð áhrif ári eftir sitkalúsarfaraldra. Niðurstöður pessarar rannsóknar benda til pess að helstu ástæður fyrir auknum sitkalúsaskemmdum í Reykjavík sé samspil hærri vetrarhita, aukinnar tíðni faraldra og hækkun á hlutfalli köfnunarefnis í nálum borgartrjáa.

\section{INTRODUCTION}

Urban trees are often subjected to greater stress than trees in a rural environment. This stress is caused by a variety of factors: small tree grids, poor soil conditions including 
compaction, unfavourable microclimates etc. (Grey \& Deneke 1978, Dahlhausen et al. 2016). Roadside and urban tree sites are typically characterized by unbalanced nutrition compositions, air pollutants, impacts of deicing salt and construction-induced root injuries (Meyer 1978, Bolsinger \& Flückiger 1987). Higher total organic nitrogen ratios have been measured in trees growing along roads as a result of pollution (Lubiarz et al. 2011), and increased nitrogen contents in leaves were reported to correlate with increased aphid densities (Bogaert et al. 2017, Megaladevi et al. 2018). Salinity, as a result of de-icing roads during winter, negatively corresponds with aphid population densities (SienkiewiczPaderewska et al. 2017). This is likely triggered by higher concentrations of $\mathrm{Na}^{+}$and $\mathrm{Cl}^{-}$in the leaves, which reduces the chlorophyll content triggering nitrogen depletion (Cekstere et al. 2008). Urban plants are also predisposed to attacks by insects due to increased contents of free amino acids in damaged tissue caused by the exposure to air-borne pollutants (Rabe \& Keeb 1979, Grill et al. 1980, Villemant 1981). As a result of these environmental stresses, trees can exhibit a decreased resistance against pest organisms, and because of the insects' thermal sensitivity in physiology, even minor changes in temperature can cause severe impacts on tree stands (Braun \& Flückiger 1984, Dohmen 1985, Lange et al. 2006).

Since the settlement of Iceland $\sim 1100$ years ago, the country has lost up to $99 \%$ of its woodland and $15-30 \%$ of its soil (Streeter et al. 2015). The forests were cut down and natural regeneration was prevented by grazing. Afforestation programs were established since the early 20th century, and various tree species were tested in Iceland though with varying success. One of the most prominent species is Sitka spruce (Picea sitchensis (Bong.) Carrière), introduced in the 1930s from Alaska. Sitka has since become one of the most widely planted tree species in Iceland (Pétursson 1999). The coastal areas of Iceland provided ideal conditions for Sitka spruce, whereas other species could not cope with the saline oceanic climate.
However, these conditions are also ideal for the Green Spruce Aphid (GSA), Elatobium abietinum Walker, a needle-feeding insect introduced to Iceland in 1959, probably imported with Christmas trees from Denmark (Blöndal 1995). GSA exclusively feeds on spruce species and occurs on its host throughout the year. Mild winter temperatures contribute to an increase of GSA population densities (Straw et al. 2019). On older trees, the aphid is usually concentrated in the lower, more shaded portions of the crown (Koot 1991). GSA thrives in oceanic climates, where it is active throughout the year and able to reproduce at minimum temperatures of $4^{\circ} \mathrm{C}$ (Crute \& Day 1990). During mass outbreaks the insect has the potential to extensively defoliate host trees and cause severe growth losses (Jackson \& Dixon 1996). By the time the needles have matured in autumn, they lose the protection of the epicuticular wax and become vulnerable to consumption at any time thereafter (Harding et al. 2003).

The first major GSA outbreak in Iceland occurred in 1964 (Nielsen et al. 2001, Halldórsson $\&$ Kjartansson 2005). Since then, eleven mass outbreaks have been recorded in the Reykjavík area (Halldórsson et al. 2013, Oddsdóttir, unpublished data). Coinciding with these events, a significant dieback of Sitka spruce alongside Miklabraut, one of the major traffic arteries in Reykjavík, has occurred. However, it remains unclear to what extent air pollution, warming of winter temperatures, and/or GSA population dynamics triggered this decline of Sitka spruce.

We hypothesise that the frequency and magnitude of GSA outbreaks are correlated with the recently changing climatic conditions, and that these combined changes influenced the dieback of Sitka spruce. We further hypothesise that pollution due to traffic in combination with warming winter temperatures made Sitka spruce more nutritious, thereby causing a higher rate of overwintering green spruce aphids. We here address this hypothesis by evaluating how GSA mass outbreaks, changing climate conditions and air quality affect Sitka spruce growth in Reykjavík, and assess how these different potential drivers of spruce growth are interlinked. 
In this paper, we first introduce the tree sites in Reykjavík (inner city and outer boundaries) as well as in Thingvellir National Park. We detail the methods used to produce and aggregate treering, defoliation, and GSA outbreak data, and analyse how these factors are inter-linked and affected by varying climatic conditions. The main findings are discussed, focusing on the role of winter and spring temperatures on the extent of GSA outbreaks and the differences between urban and non-urban trees in Iceland.

\section{MATERIALS AND METHODS}

Study design and tree-ring data

To detect tree growth reactions, samples of 76 Sitka spruce (Picea sitchensis [Bong.] Carrière) were collected in 2017 and 2018 at four different sites: (1) along the Miklabraut road (URB1), where severe dieback has been observed; (2) in Öskjuhlíð (URB2), a park located $1 \mathrm{~km}$ south of the Miklabraut road where only limited signs of recent green spruce aphid activity has been found; (3) $7 \mathrm{~km}$ south of the Miklabraut at Heiðmörk (REF1), a recreational area outside the city; and (4) a reference site $40 \mathrm{~km}$ northeast of Reykjavík at Thingvellir National Park (REF2) (Figure 1). At neither REF1 and REF2 have any GSA outbreaks been recorded. To differentiate between climate-, pollution- and insect-related growth variations, the URB1 site, located at a major traffic artery, was compared with the less affected URB2 site as well as the more natural stands REF1 and REF2. Samples from URB1 were divided into two sets: one containing only dead trees $(n=17$, URB1d) and one containing only living trees $(n=20, U R B 11)$.

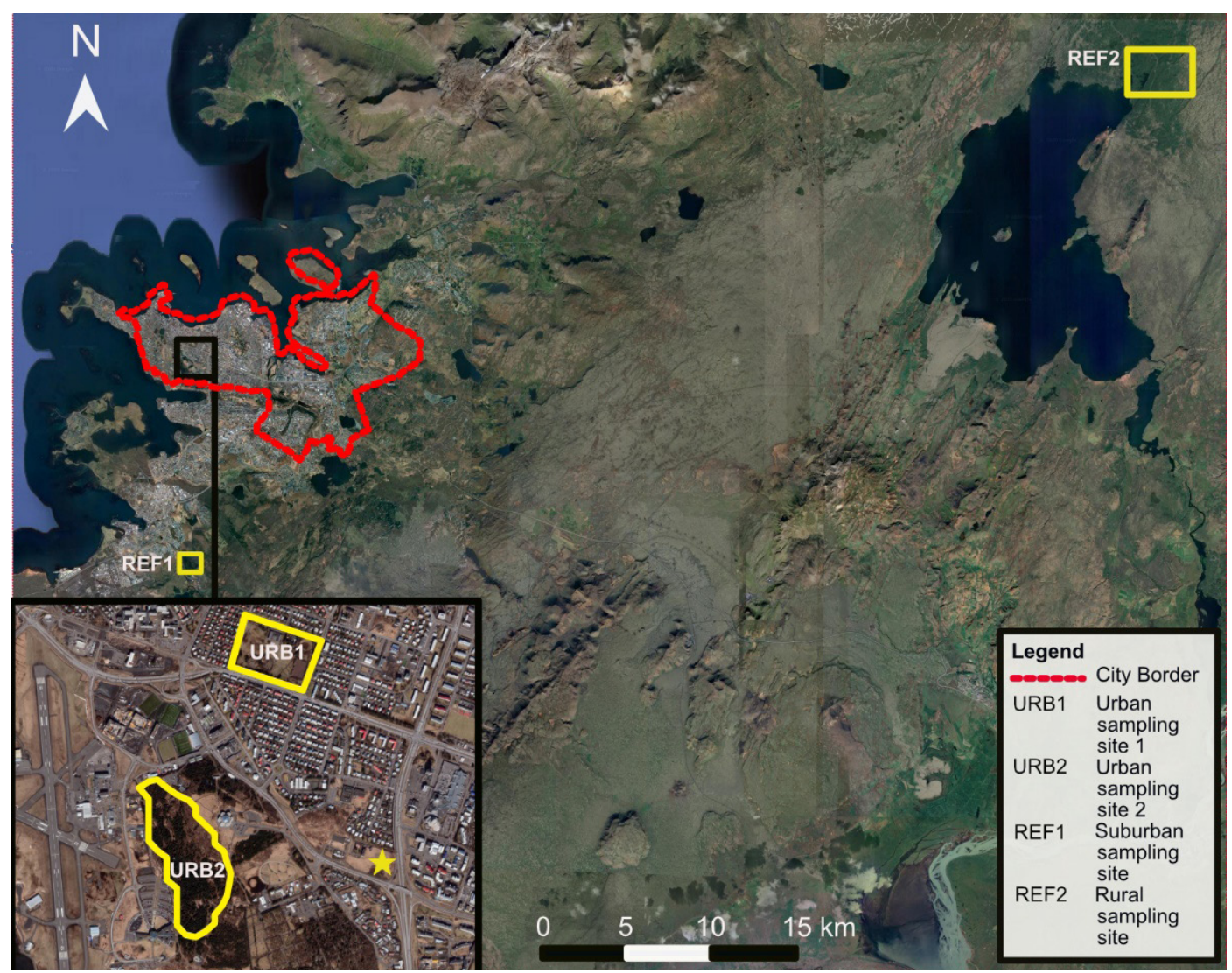

Figure 1. Map of the Reykjavík Greater Area (scale 1:500.000). Yellow squares mark the sampling sites URB1 = Miklabraut, URB2 = Öskjuhlíð, REF1 = Heiðmörk, and REF2 = Thingvellir National Park. Smaller map is a close-up of the urban sites, yellow star marks the meteorological station (scales 1:25.000). 
Table 1: Site chronology characteristics

\begin{tabular}{|l|l|l|l|l|l|l|l|l|l|l|l|l|}
\hline $\begin{array}{l}\text { Site } \\
(\text { Elev. })\end{array}$ & Coordinates & $\begin{array}{l}\text { Period } \\
\text { AD }\end{array}$ & $\begin{array}{l}\text { MSL } \\
(\mathrm{yr})\end{array}$ & $\begin{array}{l}\mathrm{n} \\
\text { trees }\end{array}$ & $\begin{array}{l}\text { Mean } \\
\text { height } \\
(\mathrm{m})\end{array}$ & $\begin{array}{l}\text { Mean } \\
\text { diam. } \\
(\mathrm{cm})\end{array}$ & AC & SD & MS & $\begin{array}{l}\mathrm{R}_{\text {bar }} \\
\text { Cof }\end{array}$ & $\mathrm{R}_{\text {bar }}$ & AGR \\
\hline $\begin{array}{l}\text { URB1d } \\
(22 \mathrm{~m})\end{array}$ & $\begin{array}{l}64.136243\left({ }^{\circ} \mathrm{N}\right) \\
-21.916137\left({ }^{\circ} \mathrm{E}\right)\end{array}$ & $\begin{array}{l}1962- \\
2016\end{array}$ & 43 & 17 & 11.6 & 30.1 & 0.59 & 0.23 & 0.36 & 0.60 & 0.40 & 3.21 \\
\hline $\begin{array}{l}\text { URB1I } \\
(22 \mathrm{~m})\end{array}$ & $\begin{array}{l}64.136243\left({ }^{\circ} \mathrm{N}\right) \\
-21.916137\left({ }^{\circ} \mathrm{E}\right)\end{array}$ & $\begin{array}{l}1961- \\
2017\end{array}$ & 47 & 20 & 13.0 & 32.2 & 0.66 & 0.25 & 0.37 & 0.48 & 0.43 & 3.21 \\
\hline $\begin{array}{l}\text { URB2 } \\
(18 \mathrm{~m})\end{array}$ & $\begin{array}{l}64.12381\left(^{\circ} \mathrm{N}\right) \\
-21.922617\left({ }^{\circ} \mathrm{E}\right)\end{array}$ & $\begin{array}{l}1973- \\
2018\end{array}$ & 40 & 13 & 12.7 & 31.8 & 0.63 & 0.35 & 0.28 & 0.46 & 0.16 & 3.50 \\
\hline $\begin{array}{l}\text { REF1 } \\
(85 \mathrm{~m})\end{array}$ & $\begin{array}{l}64.061389\left(^{\circ} \mathrm{N}\right) \\
-21.873264\left({ }^{\circ} \mathrm{E}\right)\end{array}$ & $\begin{array}{l}1963- \\
2017\end{array}$ & 41 & 16 & 15.1 & 21.5 & 0.77 & 0.33 & 0.22 & 0.62 & 0.54 & 2.41 \\
\hline $\begin{array}{l}\text { REF2 } \\
(118 \mathrm{~m})\end{array}$ & $\begin{array}{l}64.243103\left({ }^{\circ} \mathrm{N}\right) \\
-21.367002\left({ }^{\circ} \mathrm{E}\right)\end{array}$ & $\begin{array}{ll}1975- \\
2017\end{array}$ & 36 & 23 & 14.0 & 20.3 & 0.66 & 0.25 & 0.19 & 0.69 & 0.46 & 2.51 \\
\hline
\end{tabular}

URB1d = dead $P$. sitchensis chronology urban sampling site at main road, URB11 = living $P$. sitchensis chronology urban sampling site at main road, URB2 $=$ P.sitchensis chronology urban sampling site, REF1 $=P$. sitchensis suburban reference sampling site (REF1), REF2 $=P$. sitchensis rural reference sampling (REF2)

Elev. = Elevation (m.a.s.1.), MSL = mean segment length, $\mathrm{AC}=$ first-order autocorrelation, $\mathrm{SD}=$ standard deviation, $\mathrm{MS}=$ mean sensitivity, $\mathrm{R}_{\mathrm{bar}} \mathrm{Cof}=$ series intercorrelation COFECHA, Rbar = series intercorrelation, AGR = average growth rate

All trees were sampled at chest-height using a 5-mm increment corer. Two samples were collected from each individual tree. Treering width (TRW) was measured at a precision of $0.01 \mathrm{~mm}$ using a LINTAB measurement device together with the TSAP-Win software (Rinn 2003). The dating quality was verified using the COFECHA software (Holmes 1983), and the TRW data were detrended using the ARSTAN software by calculating ratios from cubic smoothing splines with a frequency cutoff of $50 \%$ at 30 years $\left(\mathrm{RWI}_{30}\right)$ to emphasize high-frequency variability for GSA detection analyses (Cook 1985). Descriptive statistics of raw chronologies include the average growth rate (AGR), mean segment length (MSL) and first-order autocorrelation (AC-1). The interseries correlation $\left(\mathrm{R}_{\text {bar }}\right)$ was considered to describe the mean correlation among all series (Fritts 1976). In COFECHA, $\mathrm{R}_{\text {bar }}$ refers to the correlation of each series with a master chronology comprising all remaining samples, which is here indicated as $\mathrm{R}_{\mathrm{bar}}$ Cof (Table 1). Throughout this study we used spline-detrended data for analysis.

The presence of GSA was determined at URB1 and URB2 by searching the underside of the needles of five different branches spread evenly around the lower crown. Furthermore, the defoliation intensity of each Sitka spruce was assessed visually and the damage divided into four classes: unaffected (0-10\% defoliation), lightly affected (11-30\% defoliation), moderately affected (31-60\% defoliation), and heavily affected (61-100\% defoliation). To determine the most recent year affected by defoliation, on each branch the sections between two shoots were counted backward until a section exceeded $70 \%$ needle loss. If this method did not return a defoliation event for more than 10 years (sections), we concluded that no defoliation event had occurred since 2009. If no foliage was present on the lower crown, the tree was excluded from this assessment of defoliation years. A total of 171 of the living trees at URB1 and 238 trees at URB2 were used in this analysis (Figures 2 and 3).

\section{Climate and air quality data}

To study growth-climate relationships, instrumental temperature and precipitation records were used (Figure 4). The nearest meteorological station in Reykjavík is located at an altitude of $52 \mathrm{~m}$ a.s.l. approximately one $\mathrm{km}$ south-east of URB1 and 500 m east of URB2, as well as $7 \mathrm{~km}$ north of REF1 and $40 \mathrm{~km}$ southwest of REF2 (Icelandic Meteorological Office 2019).

Air quality data from the Environment 


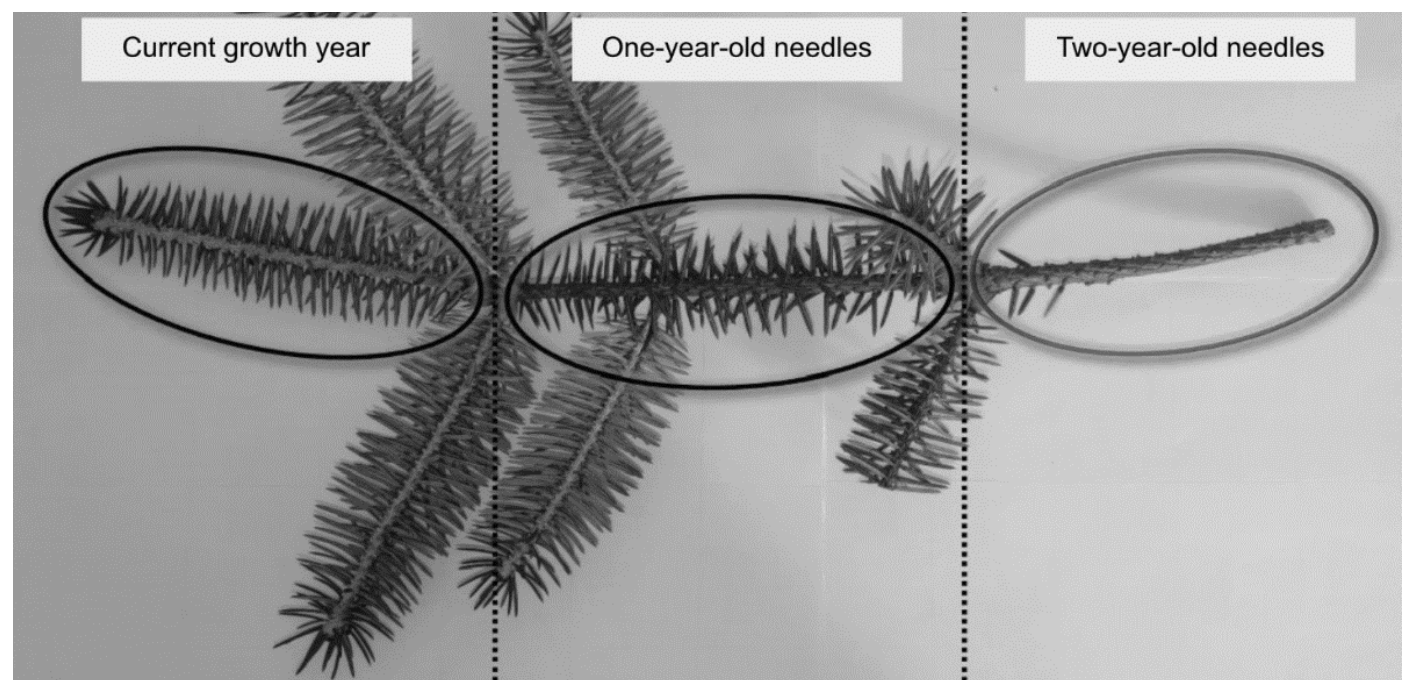

Figure 2. Branch of Sitka spruce. The two-year-old needles have almost completely fallen off and chlorosis can be seen on the rightmost needle.

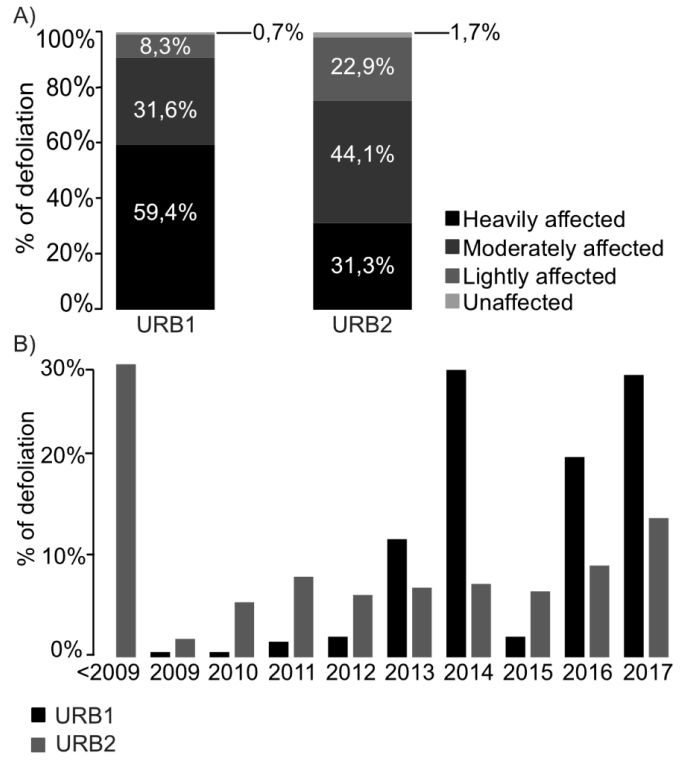

Figure 3. (A) Defoliation intensities in sites URB1 $(\mathrm{n}=288)$ and URB2 $(\mathrm{n}=288)$, and $(\mathrm{B})$ temporal changes of heavy defoliations from 2009-2017.

Agency of Iceland (Jóhannsson, personal communication) were used to compare changes in $\mathrm{NOx}, \mathrm{NO}_{2}, \mathrm{NO}$ and $\mathrm{SO}_{2}$ with the meteorological, TRW and insect outbreak data.
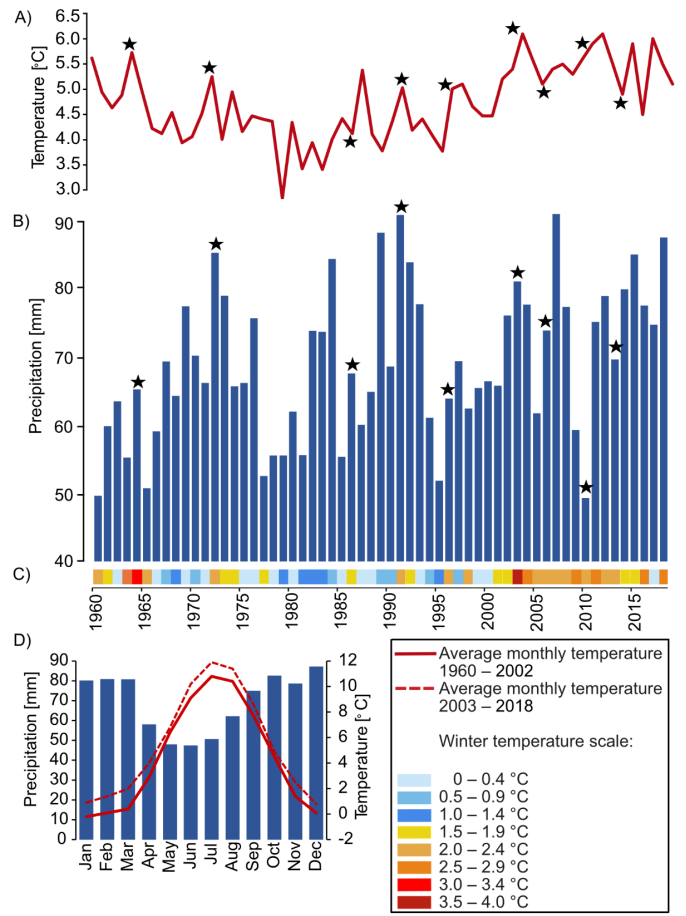

Figure 4. Reykjavík climate data. (A) Winter temperature (Oct-Mar), and (B) annual precipitation records from 1960-2018. (C) Same as in (A), but using a colour coding. (D) Climate diagram showing monthly precipitation and temperature. The solid and dashed red curves highlight the temperatures from 1960-2002 and 2003-2018, respectively. Black stars in (A) and (B) mark the GSA outbreak years 1964 , 1972, 1986, 1991, 1996, 2003, 2006, 2010 and 2013. 
Hourly air quality data from 2003-2016 were transformed into monthly and annual means for a better comparison with the meteorological and TRW data. A clear seasonal pattern can be seen in $\mathrm{NO}_{\mathrm{x}}, \mathrm{NO}_{2}, \mathrm{NO}$ and $\mathrm{SO}_{2}$, which were all substantially increased in winter due to increased traffic and studded tires (Icelandic Road and Coastal Administration (IRCA) 2018).

\section{Chemical analysis of spruce needles}

Chemical studies as well as the determination of green spruce aphid presence were performed in 2018 at the sites URB1 and URB2. Five trees from each site were randomly selected using QGIS (Open source, v3.4.1), and total organic nitrogen ratios, chloride concentrations and sodium levels measured (Table. 2). Roughly 50 needles per tree were collected from the lower third of the selected trees at both sites. The needles were weighed and subsequently dried at $30^{\circ} \mathrm{C}$ for 88 hours. Dry weight was determined, and the samples were dry grinded using a Retsch MM200 mill for 25 seconds at 30 vibrations per second. The samples were subsequently sent to Efnagreining EHF, Hvanneyri, for determination of Total Nitrogen using the Kjeldahl method (TKN) (Kjeldahl 1883).

\section{Statistical analysis}

GSA outbreaks were identified by assessing anomalies in the mean TRW site chronologies.
TRW deviations were compared with monitored and documented GSA outbreaks in Reykjavík (Halldórsson et al. 2013). In addition, the tree rings subsequent to these outbreak events were evaluated using superposed epoch analysis (SEA; Panofsky \& Brier 1958). This was achieved by aligning (= year 0 in SEA) the $\mathrm{RWI}_{30}$ chronologies considering reported GSA outbreaks. SEAs were subdivided in terms of outbreaks that occurred in autumn (1964, 1972, 1986, 1991, 1996) and spring (2003, 2006, 2010, 2013), and the growth deviations 5 years before and after these events were compared. In the SEA, tree growth is expressed as scaled TRW anomalies with respect to the mean of the 5 years preceding an event (years -5 to -1 Figure 5, Esper et al. 2013).

To analyse similarities in year-to-year TRW variability among the sites URB1, URB2, REF1 and REF2, the average correlation among RWI $_{30}$ chronologies (Site-R $\mathrm{R}_{\text {bar }}$ ) was determined. A pointer year analysis (PYA) according to Cropper (1979) was performed to detect growth anomalies. In this procedure, a 13-year weighted high-pass filter (Fritts 1976) was applied to the TRW series prior to the calculation of pointer years. We then calculated z-scores by transforming the annual measurements series in terms of a 13-year symmetric moving arithmetic mean. The changing standard deviations are expressed by the $\mathrm{C}$-values (Cropper values) as

Table 2. Chemical results of the needle samples taken at URB1 and URB2. Outliers are indicated with an *

\begin{tabular}{lccccc}
\hline Site & Sample & Total $\mathbf{~ \% ~}$ & $\mathbf{C l}$ in $\mathbf{g} / \mathbf{k g}$ & $\mathbf{N a}$ in $\mathbf{g} / \mathbf{k g}$ & $\mathbf{K}$ in $\mathbf{~} / \mathbf{k g}$ \\
\hline URB1 & 1 & 1.55 & $0.6^{*}$ & 0.85 & 6.35 \\
& 2 & 1.44 & 0.1 & 2.47 & 5.69 \\
& 3 & 1.44 & $0.6^{*}$ & 1.68 & 5.41 \\
Average & 4 & 1.16 & $<0.1$ & 1.40 & 9.17 \\
\hline URB2 & 5 & 1.35 & $<0.1$ & 1.40 & 8.70 \\
& & $\mathbf{1 . 3 9}$ & $\mathbf{0 . 4 4}$ & $\mathbf{1 . 6 4}$ & $\mathbf{7 . 0 7}$ \\
\hline & 1 & 0.94 & $<0.1$ & 0.29 & 5.08 \\
& 2 & 0.91 & $<0.1$ & 1.42 & 4.63 \\
Average & 3 & 1.30 & $<0.1$ & 0.20 & 5.57 \\
& 4 & $1.89 *$ & 0.3 & 0.24 & 9.38 \\
& 5 & 1.07 & 0.1 & 0.91 & 5.59 \\
\end{tabular}




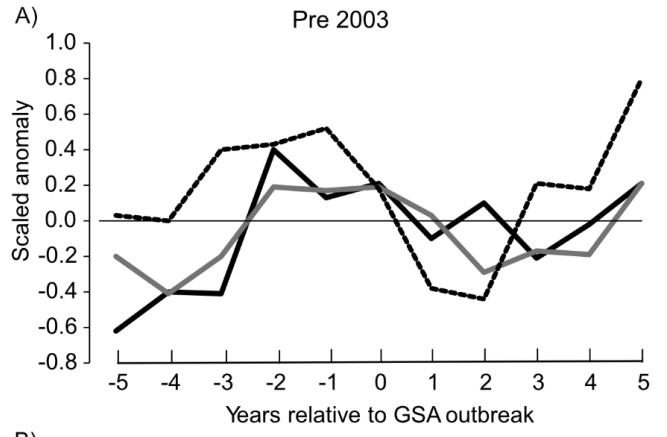

B)

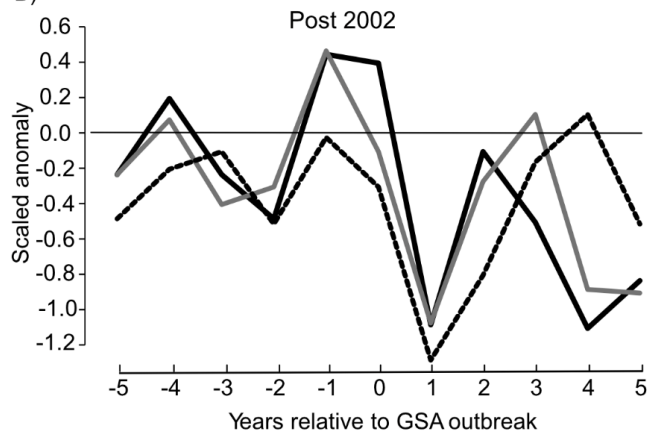

Figure 5. SEA considering the autumn outbreaks before 2003 (A), and the spring outbreaks after 2003 (B). Different colours refer to URB1d chronology from dead Sitka spruce chronology in black, the URB11 chronology from living trees in grey (both urban sites), and the REF1 chronology in black (dotted). 30year spline detrended ring width indices were used in the SEA. Records are aligned (= year 0 ) by GSA outbreaks.

TRW deviations from the 13-year running mean (Fischer \& Neuwirth 2012). We used the 0.75 and -0.75 thresholds for the $\mathrm{C}$-value to define event years, and $75 \%$ of all data in a given year to define a positive or negative pointer year (Cropper 1979).

Between-site defoliation events were compared using a chi-square test, after merging the 'unaffected' $(0-10 \%$ defoliation $)$ and 'lightly affected' (11-30\%) groups. The 'heavily affected' (61-100\% defoliation) group was tested individually. Temporal differences in the last year of a defoliation were assessed utilizing an ANCOVA test (Miller \& Chapman 2001), and total organic nitrogen, sodium $(\mathrm{Na}+)$ and chloride (Cl-) contents were compared between URB1 and URB2 using an independent sample T-test (Kim 2015). Furthermore, we looked into the equality of variances using Levene's test (Levene 1960) which is used to test whether $\mathrm{k}$ samples have equal variances. The Levene test can be used to verify the assumption that variances are equal across groups/samples.

\section{RESULTS}

\section{Characteristics of tree-ring data}

The average growth rate (AGR) of Sitka spruce is highest at URB1 $(3.21 \mathrm{~mm} /$ year $)$ and lowest at REF1 (2.41 mm/year) (Table 1). Since all trees have been planted in the 1960-70's, the mean segment lengths (MSL) were relatively even and ranged from 36 years in REF2 to 47 years in URB1. Lag-1 autocorrelations were lowest in the chronology from dead trees at URB1 (0.59) and highest in REF1 (0.77), and the $\mathrm{R}_{\mathrm{bar}}$ values ranged from 0.16 in URB2 to 0.54 in REF1. The Sitka spruce TRW site chronologies of URB1 $(\mathrm{AC}=0.66)$ and $\mathrm{URB} 2(\mathrm{AC}=0.63)$ were closely correlated from 1961-2017, which was expected as they are both located in Reykjavík city. However, after 2003 the trees in URB2 showed a significantly higher overall growth and less negative outlier years compared to URB1 (Figure 6).

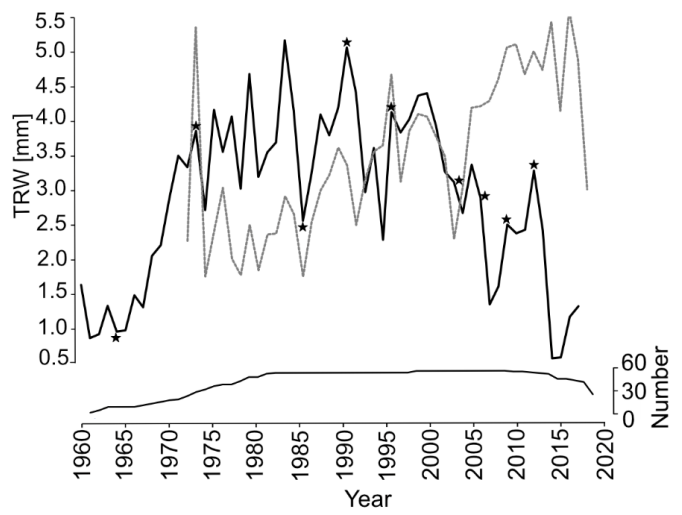

Figure 6. Annually resolved TRW chronologies (in $\mathrm{mm}$ ) of Sitka spruce trees at URB1 (black) and URB2 (grey, dotted). Bottom curve shows total replication. Stars mark the GSA outbreak years 1964, 1972, 1986, 1991, 1996, 2003, 2006, 2010 and 2013. 


\section{Climate data}

The meteorological station in Reykjavík recorded an annual average temperature of $4.9^{\circ} \mathrm{C}$ and precipitation of $828 \mathrm{~mm}$ in the period from 1960 to 2019. Mean annual temperatures in Reykjavík increased by over $1^{\circ} \mathrm{C}$ during the last decades. The year 2003 was exceptionally warm with an average winter (Nov-Apr) temperature of $3.9^{\circ} \mathrm{C}$, and winter temperatures have thereafter almost constantly been above $2^{\circ} \mathrm{C}$, compared to the average of $1.3^{\circ} \mathrm{C}$ from 1960 2002 (Figure 4). In Figure 4C, most of the dark orange and red spaces indicating winters colder than $3.5^{\circ} \mathrm{C}$ were aligned with GSA outbreaks, whereas the dark red space $\left(>3.5^{\circ} \mathrm{C}\right)$ in the right part of the figure marks the year 2003. The temperature data were therefore separated into two periods, 1960-2002 and 2003-2019, to examine the differences between these periods as the change of outbreak pattern occurred in 2003. The summer, winter and annual mean temperatures increased since 2003 by $>1^{\circ} \mathrm{C}$. During nearly all (autumn and spring) GSA outbreaks, winter temperatures were relatively high, mostly exceeding climatology by $2^{\circ} \mathrm{C}$ (except in $1986=1.6^{\circ} \mathrm{C}$ ).

In addition to temperature, precipitation also increased in Reykjavík, particularly during winter. Summer precipitation slightly decreased after 2003. However, the data show that the particularly dry years did not coincide with mass outbreaks in the sampling sites.

\section{GSA outbreaks and growth anomalies}

A significantly higher proportion of trees at URB1 had GSA present (21.6\%), compared to URB2 $(8.4 \%)$. Temporal alignment of the growth data during documented GSA outbreaks using SEA showed no consistent pattern for the autumn outbreaks recorded before 2003 (Figure 5A). A distinct growth suppression was retained, however, in the post-2003 TRW data in response to the spring outbreaks. It is notable that the dead-tree chronology (URB1d) recovered faster after an GSA outbreak, whereas the living-tree chronologies (URB11 and REF1) persisted on a lower level, before recovering in years 2 to 3 subsequent to an outbreak (Figure
5). The PYA demonstrates that positive pointer years coincided with outbreaks, whereas most pointer years that occurred one year after an outbreak were negative, thereby reinforcing the results of the SEA.

\section{Air quality, nitrogen content and salinity}

The chemical analysis of five needle generations showed that the total organic nitrogen ratio was fairly similar among the tree sites ( $p>0.05$; Table 2), with an equality of variances of 0.11 among the samples. When excluding the outlier from URB2, equality of variances reached 0.70 and the total organic nitrogen ratio at URB1 became significantly higher than in URB2 $(\mathrm{p}<0.05)$. At a low sample equality, and therefore higher standard deviation, an independent T-test was less likely to indicate a significant difference, because it takes the probability of outliers into account. Therefore, removing the single outlier from the analysis of URB2 (Table 2, marked with an *) resulted in a significant difference between URB1 and URB2 as the results became more similar within the groups. $\mathrm{Na}^{+}$levels were significantly higher in URB1 than in URB2 $(\mathrm{p}<0.05)$, at an equality of variances of $0.87 . \mathrm{Cl}^{-}$levels of the samples were statistically indistinguishable $(p>0.05)$ with URB1 showing two outliers and an equality of variances of only 0.001 . The $\mathrm{Cl}^{-}$concentrations of the needles showed no significant differences, as the variance among samples was rather high, expressed by an equality of variances of 0.001 . Also, $\mathrm{Na}^{+}$concentrations were significantly higher in URB1 than in URB2.

No correlation was found between $\mathrm{NO}, \mathrm{NO}_{x}$, $\mathrm{NO}_{2}$ compared to TRW and GSA outbreaks. These results are constrained by the numbers of data points, as no air quality data from before 2003 were available. $\mathrm{NO}, \mathrm{NO}_{\mathrm{x}}$ and $\mathrm{NO}_{2}$ values were generally higher during winter, but the values remained relatively stable between 2003 and 2018, except for a decrease in 2009. The same applied for $\mathrm{SO}_{2}$ (Figure 7).

\section{Defoliation of Sitka spruce}

A significant difference in the distribution of defoliation classes was recorded between URB1 


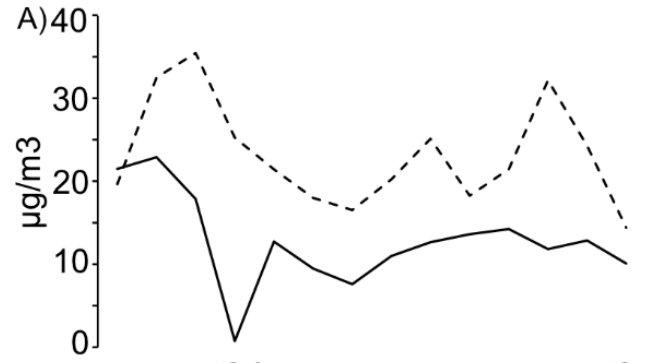

B)
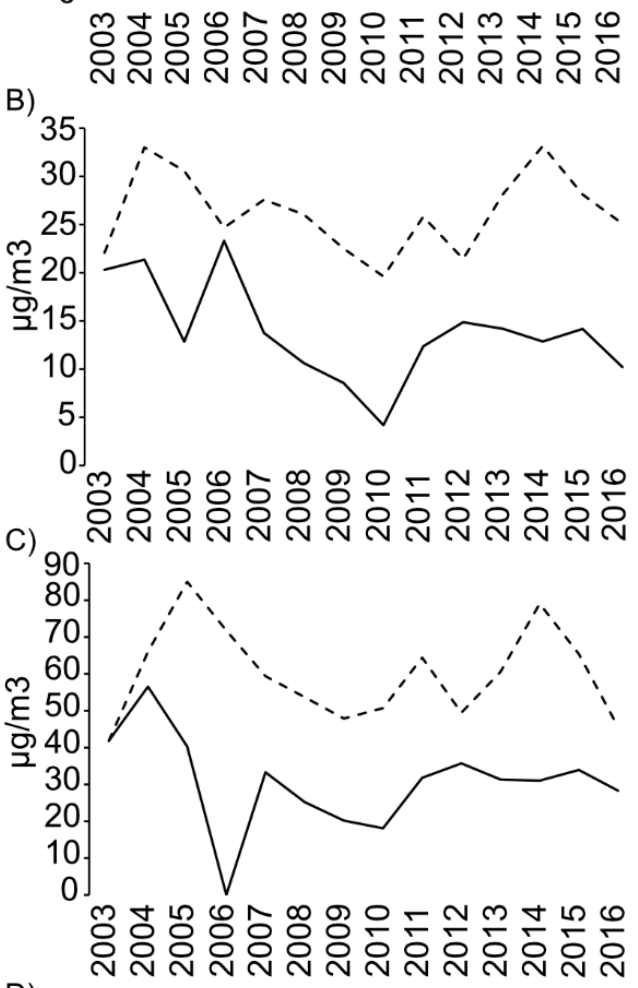

D)

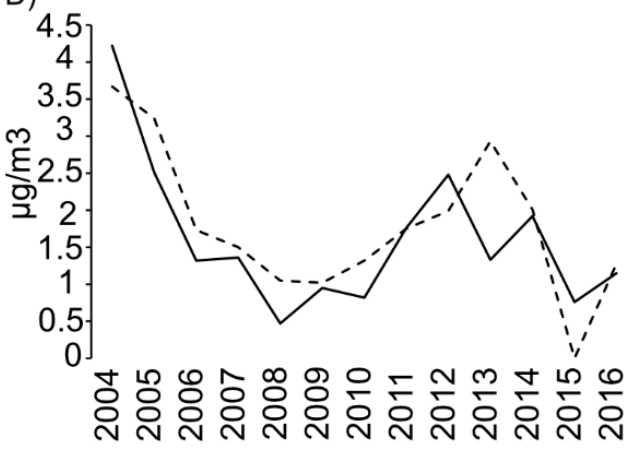

Figure 7. Development of air quality in Reykjavík including values for (A) $\mathrm{NO}$, (B) $\mathrm{NO}_{2},(\mathrm{C}) \mathrm{NOx}$, and (D) $\mathrm{SO}_{2}$ during winter (Oct-Mar; dotted line) and summer (Jun-Aug; solid line) from 2003-2018. and URB2 $(p<0.05)$. In URB1, 59.4\% of the Sitka spruce were heavily affected, compared to only $31.3 \%$ in URB2. Further indicators of differences were detected in the most recent defoliation events fingerprinted in the branches. The values of this analysis represent a significant difference between URB1 and URB2 $(\mathrm{p}<0.05)$. In URB1, 94\% of the trees were defoliated during 2013-2017, compared to only $47 \%$ at URB2. In general, URB2 showed a more even distribution of defoliation years among the trees.

\section{DISCUSSION}

The effects of GSA outbreaks and nutritional quality of spruce trees due to pollution from heavy traffic have been examined in northern European countries including Great Britain (Port \& Thompson 1980, Carter \& Nichols 1988). However, no study on GSA behaviour in combination with changing climate and pollution has been done in Iceland. In the present study, changes in TRW and GSA outbreak patterns, as well as differences in chemical contents of Sitka spruce needles were investigated to gain knowledge about the interrelations between tree growth and potential drivers. Since the 1960s the number and severity of GSA outbreaks in Reykjavík has increased, and since 2003 five outbreaks occurred in only 14 years, whereas in the 42 years before 2003 only six outbreaks were recorded (Halldórsson \& Kjartansson 2005, Halldórsson et al. 2013).

The high amount of nitrogen in the needles of URB1 trees is probably caused by the traffic alongside this sampling site (Lubiarz et al. 2011). When excluding an outlier in total N\% from the URB2 data (sample 4, Table 2), the equality of variances is 0.70 , indicating that the total $\mathrm{N} \%$ values are relatively stable. In so doing, the total organic nitrogen ratio in URB1 is significantly higher than in URB2 $(\mathrm{p}<0.05)$. For $\mathrm{Cl}^{-}$, the ions have a high solubility, resulting in a high mobility within plants (Zítkova et al. 2018). This causes $\mathrm{Cl}^{-}$to be washed out or moved from older needles to younger ones. The $\mathrm{Na}^{+}$concentrations were again significantly higher in URB1 than in URB2 indicating salt stress. Also, roadside salinity has been shown to 
lower chlorophyll levels in needles (Cekstere et al. 2008).

Environmental changes such as higher temperatures and favourable levels of nitrogen and $\mathrm{SO}_{2}$ input through traffic, particularly during winter, may predispose the Sitka spruce to more and severe GSA attacks (Malhotra \& Sarkar 1979, Villemant 1981). As the peak of aphid populations was typically associated with an improved host plant nutrition quality, the seasonal shift of outbreaks from autumn to spring, might also be triggered by elevated $\mathrm{N}$ and $\mathrm{SO}_{2}$ levels in winter acting as fertilizers. Because of a higher pollution in winter, the spruce trees in URB1 alongside the busy road received more nutrition and probably became more vulnerable to GSA outbreaks. The fertilizing effect of nitrogen was also reflected in a higher AGR of URB1 trees compared to the REF1 and REF2 stands outside the city. Similar nitrogen effects have been shown in other countries to improve tree growth (Anderson \& Mansfield 1979, Yoneyama et al. 1980).

Within-year aphid population changes are affected by the nutrient availability in spruce needles (Day \& Kidd 1998). Hence, the change of outbreak seasonality, from autumn to spring, in Reykjavík could have been due to the higher input of $\mathrm{N}$ and $\mathrm{SO}_{2}$ during the cold season compared to the stands outside the city centre, but the effects of warming temperatures have to be taken under consideration too. It is likely that $\mathrm{N}$ and $\mathrm{SO}_{2}$ acted as fertilizers for the trees and, together with warmer winter temperatures, created favourable conditions for GSA population development. Increased salinity due to road de-icing has been shown to correlate negatively with aphid population densities (Sienkiewicz-Paderewska et al. 2017). During warmer winters, when less de-icing takes place, the aphid populations increase. Also, low temperatures are responsible for a higher mortality of the GSA (Day \& Kidd 1998, Halldórsson et al. 2001). The chemical analyses, however, still showed that sodium levels in trees alongside URB1 were elevated, indicating persistent salt stress in those trees. We therefore conclude that the influence of a higher nitrogen input through traffic plus warm winter temperatures in Reykjavík probably had a stronger influence on the GSA populations at URB1 than the effects of de-icing. This combination supports the conclusion of large overwintering GSA populations triggering mass outbreaks.

During the 2013-2017 period, the URB1 site experienced stronger defoliations compared to URB2 (Figure 3). Defoliation of both deciduous and coniferous trees in northern European countries passing a threshold of $80 \%$ typically coincide with significant growth declines in subsequent years and higher rates of mortality (Cedervind \& Långström 2003). The repeated defoliation at a high intensity in URB1 could indicate that this threshold was exceeded and that the trees had insufficient time to recover, which eventually stimulated dieback. In URB2, $8.4 \%$ of the trees had aphids present on the lower parts of the crown, but aphid coverage at URB1 reached $21.6 \%$, causing increased damage of Sitka spruce at this site. The defoliation differences between single years, and the way such events were distributed across the sampling sites, demonstrated that region-wide outbreaks were rare. Instead, severe defoliation seems to have occurred at the individual-tree level, which could be have been instigated by the changing microclimates in the Reykjavík urban environment.

The results of the SEA and the PYA showed that (reconcerning the spring outbreaks) the year of the outbreak event was characterized by regular growth, whereas the year subsequent to an outbreak showed negative growth anomalies (negative pointer year). Even though SEA revealed that the dead URB1 trees recovered faster in warmer conditions (after 2002), compared to URB2 and REF1 (Figure. 5 $\mathrm{B})$, the overall growth rate was lower at this site. In contrast, the trees at URB2 and REF1 needed more time to recover but grew faster. One reason for the fast recovery of trees in URB1 might have been a general adaptation to a stressful environment near traffic. But still the dieback was severe in URB1, showing that a faster recovery was not preventing the trees 
from dying. These findings indicate that spruce stands which are less affected by traffic, might need more time to recover from a GSA mass outbreak, whereas the tree-ring data indicate that much fewer outbreaks occurred in REF1 and URB2 compared to URB1. The trees exposed to heavy traffic showed a significant dieback, even though recovery after a mass outbreak was faster.

\section{CONCLUSIONS}

The frequency and intensity of GSA outbreaks on Sitka spruce at an urban site near the main road in Reykjavík has increased significantly since 2003. This increase was likely caused by changing climatic conditions and pollution levels, which led to a dieback of Sitka spruce in Iceland's capital. An exceptionally warm winter in 2003 seems to have altered the basic outbreak pattern of GSA, shifting from autumn to spring events. Climate variability alone, however, cannot explain the difference in defoliation and aphid occurrence among Sitka spruce stands in Reykjavík. We also linked growth anomalies at urban and non-urban sites in Iceland to documented GSA outbreaks and showed that the urban trees close to the main road were attacked more often and were affected more strongly by defoliation, compared to stands which were not influenced by heavy traffic. We also showed that although pollution, salinity and GSA can have combined, suppressing and enhancing effects on Sitka spruce, those factors had exclusively suppressing effects on our urban sampling site. Higher $\mathrm{N}$ values in the needles of the urban Sitka spruce trees probably contributed to the repeated and more severe GSA outbreaks in this area. The difference in needle total organic nitrogen ratios could have been recorded in both urban and non-urban areas over a longer period and linked to both traffic density and GSA abundance. A cutdown of infested Sitka could be feasible, but this would mean the removal of more than 60 adult trees alongside the main Miklabraut road. Another remedy against the dieback could be the use of pesticides in order to protect spruce needles against GSA attacks. In addition, a different tree species requiring less nutrient rich soils and resilient to aphid outbreaks could be planted to survive the stressful Miklabraut environment. A long-term monitoring of seasonal tree growth (height and diameter) as well as air quality and nitrogen deposition could give further insight into the role of traffic and GSA on Sitka spruce on Iceland.

\section{REFERENCES}

Anderson LS, Mansfield TA 1979. The effects of nitric oxide pollution on the growth of tomato. Environmental Pollution 20, 113-121.

https://doi.org/10.1016/0013-9327(79)90063-6

Blöndal S 1995. Innfluttar trjátegundir í Hallormsstaðaskógi. [Introduced trees in Hallormsstadarskogur]. Iceland Forest Service, Egilsstadir: 56. [In Icelandic].

Bogaert F, Chesnais Q, Catterou M, Ramboud C, Doury G \& Ameline A 2017. How the use of nitrogen fertiliser may switch plant suitability for aphids: the case of Miscanthus, a promising biomass crop, and the aphid pest Rhopalosiphum maidis. Pest Management Science 73 (8), 1648-1654. https://doi.org/10.1002/ps.4505

Bolsinger M, Flückiger W 1987. Enhanced aphid infestation at motorways: the role of ambient air pollution. Entomologia Experimentalis et Applicata 45, 237- 243. https://doi.org/10.1111/j.1570-7458.1987.tb01089.x

Braun S, Flückiger W 1984. Increased population of the aphid Aphis pomi at a motorway. Part 1. Field evaluation. Environmental Pollution (Series A) 33, 107-120.

https://doi.org/10.1016/0143-1471(84)90171-5

Carter CI, Nichols JFA 1988. The Green Spruce Aphid and Sitka spruce Provenances in Britain. Forestry Commission Occasional Paper 19, 50.

Cedervind J, Långström B 2003. Tree Mortality, Foliage Recovery and Top-kill in Stands of Scots Pine (Pinus sylvestris) subsequent to Defoliation by the Pine Looper (Bupalus piniaria). Scandinavian Journal of Forest Research 18, 505-513. https://doi.org/10.1080/02827580310018569

Cekstere G, Nikodemus O \& Osvalde A 2008. Toxic impact of the de-icing material on street greenery in Riga, Latvia. Urban Forestry \& Urban Greening 7 (3), 207-217.

https://doi.org/10.1016/j.ufug.2008.02.004 
Cook E 1985. A time series analysis approach to tree ring standardization. University of Arizona.

Cook E, Peters K 1997. Calculating unbiased tree-ring indices for the study of climatic and environmental change. In: The Holocene 7 (3), 361-370.

https://doi.org/10.1177/095968369700700314

Cropper JP 1979. Tree-ring skeleton plotting by computer. In: Tree-Ring Bulletin 39, 47-59.

Crute SJ, Day KR 1990. Understanding the impact of natural enemies on spruce aphid populations through simulation modelling. In: Watt $\mathrm{AD}$, Leather SR, Hunter MD \& Kidd NAC (eds.) Population dynamic of forest insects. Intercept, Andover: 329-337.

Dahlhausen J, Biber P, Rötzer T, Uhl E \& Pretzsch H 2016. Tree Species and Their Space Requirements in Six Urban Environments Worldwide. Forests 20167 (111), 1-19.

https://doi.org/10.3390/f7060111

Day KR, Kidd NAC 1998. Green spruce aphid population dynamics: effects of climate, weather and regulation. In: Day KR, Halldórsson G, Harding S \& Straw NA. The Green Spruce Aphid in Western Europe; ecology, status, impacts and prospects for management. Forestry Commission, Technical Paper 24, 41-52.

Dohmen GP 1985. Secondary effects of air pollution: enhanced aphid growth. Environmental Entomology A 39, 227-234.

https://doi.org/10.1016/0143-1471(85)90099-6

Esper J, Schneider L, Krusic PJ, Luterbacher J, Büntgen U, Timonen M, Sirocko F \& Zorita E 2013. European summer temperature response to annually dated volcanic eruptions over the past nine centuries. Bulletin of Volcanology 75, 736. https://doi.org/10.1007/s00445-013-0736-z

Fischer S, Neuwirth B 2012. Klimasensitivität in Eifel und Kellerwald. Allgemeine Forst- und Jagdzeitung 2012, 1: 23-33.

https://doi.org/10.1155/2013/201360

Fritts HC 1976. Tree rings and climate. Caldwell N.J.: Blackburn Press.

https://doi.org/10.1016/B978-0-12-268450-0.X5001-0

Grey KM, Deneke FJ 1978. Urban Forestry. John Wiley Ed., New York.

Grill D, Esterbauer H, Scharner M \& Felgitsch C 1980. Effect of sulphur-dioxide on protein-SH in needles of Picea abies. European Journal of Pathology 10, 263-267.

https://doi.org/10.1111/j.1439-0329.1980.tb00038.x

Halldórsson G, Docherty M, Oddsdóttir ES \& Day KR 2001. The performance of different populations of the green spruce aphid (Elatobium abietinum Walker) at different temperatures. Icelandic Agricultural Sciences, 14, 75-84.

Halldórsson G, Kjartansson B 2005. Sitkalús [The green spruce aphid]. In: Ægisson $\mathrm{S}$ (ed.) Á sprekamó. Afmcelisrit tileinkađ Helga Hallgrímssyni sjötugum: 107-115. [In Icelandic].

Halldórsson G, Sigurdsson BD, Hrafnkelsdóttir B, Oddsdóttir ED, Eggertsson Ó \& Ólafsson E 2013. New arthropod herbivores on trees and shrubs in Iceland and changes in pest dynamics: A review. Icelandic Agricultural Sciences 26, 69-84.

Harding S, Roulund H \& Wellendorf H 2003. Consistency of resistance to attack by the green spruce aphid (Elatobium abientinum Walker) in different ontogenetic stages of Sitka spruce. Agricultural and Forest Entomology 5, 107-112.

https://doi.org/10.1046/j.1461-9563.2003.00175.x

Holmes R 1983. Analysis of tree rings and fire scars to establish fire history. In: Tree-Ring Bulletin 43, 51-67.

Icelandic Meteorological Office 2019. Reykjavík - weather station - information. Source: http:// en.vedur.is/weather/stations/?s=rvk (13.09.2019).

Icelandic Road and Coastal Administration (IRCA) 2018. Daily Traffic in Reykjavík city. Source: https://www.google.com/url?sa=t\&rct=j\&q=\&esrc $=$ s\&source $=$ web $\& c d=1 \& v e d=0$ ahUKEwjah $9 \mathrm{Cu} 6 \mathrm{~L}$ fcAhWRbVAKHatnDFsQFggpMAA\&url=http $\% 3$ $\mathrm{A} \% 2 \mathrm{~F} \% 2 \mathrm{Fwww}$.vegagerdin.is $\% 2 \mathrm{Fvefur} 2 . \mathrm{nsf} \% 2 \mathrm{~F}$ Files $\% 2 \mathrm{Fhb} 2018 \% 2 \mathrm{~F} \% 24 \mathrm{file} \% 2 \mathrm{FHb} \% 25 \mathrm{C} 3 \% 2$ 5A1_neti\%25C3\%25B0_2018.pdf\&usg=AOvVaw 3GZ2WqDnfvkAxBtXjRJNfV (24.07.2018).

Jackson D, Dixon A 1996. Factors determining the distribution of the green spruce aphid, Elatobium abietinum, on young and mature needles of spruce. Ecological Entomology 21(4), 358-364. dx.doi.org/10.1046/j.1365-2311.1996.t01-1-00026.x

Jóhannsson P 2018. Air Quality data from Grensás. Personal correspondence with P. Jóhannsson from the Department for Nature (Umhverfisstofnun), Environment Agency of Iceland. Received: 30.04.2018. 
Kim TK 2015. T test as a parametric statistic. Korean Journal of Anesthesiology. 68 (6), 540-546. dx.doi.org/10.4097/kjae.2015.68.6.540

Kjeldahl J 1883. Neue Methode zur Bestimmung des Stickstoffs in organischen Körpern. Fresenius, Zeitschrift für analytische Chemie 22, 366-382. https://doi.org/10.1007/BF01338151.

Koot HP 1991. Spruce Aphid. Forest Pest Leaflet. 16. Victoria, BC. Forestry Canada.

Lange H, Økland B \& Krokene P 2006. Thresholds in the life cycle of the spruce bark beetle under climate change. InterJournal for Complex Systems: 1648.

Levene H 1960. Robust tests for equality of variances. In: Olkin I, Hotelling H Contributions to probability and statistics: Essays in Honor of Harold Hotelling. Stanford University Press: 278292.

Lubiarz M, Cichocka E \& Goszczyński W 2011. Landscape type and species richness and composition of Arthropoda Part II. Urban landscape. Aphids and Other Hemipterous Insects 17, 39-51.

Malhotra SS, Sarkar SK 1979. Effects of sulphur dioxide on sugar and free amino acid content of pine seedlings. Physiologia Plantarum 47, 223228.

https://doi.org/10.1111/j.1399-3054.1979.tb06517.x

Megaladevi P, Pallavi D, Manunatha M \& Sharanabasappa M 2018. Effect of nitrogen fertilizer on population of aphid [Brevicoryne brassicae (L.)] in radish. International Journal of Current Microbiology and Applied Sciences 7(2), 142-248.

https://doi.org/10.20546/ijcmas.2018.702.018

Meyer FH 1978. Bäume in der Stadt. Verlag Eugen Ulmer Ed., Stuttgart: 327.

Miller GA, Chapman JP 2001. Misunderstanding Analysis of Covariance. Journal of Abnormal Psychology, 110 (1), 40-48.

http://dx.doi.org/10.1037//0021-843X.110.1.40

Nielsen C, Eilenberg J, Harding S, Oddsdottir E \& Halldórsson G 2001. Geographical distribution and host range of Entomophthorales infecting the green spruce aphid Elatobium abietinum Walker in Iceland. Journal of invertebrate pathology, 78 (2), 72-80.

https://doi.org/10.1006/jipa.2001.5045
Panofsky HA, Brier GW 1958. Some applications of statistics to meteorology. Mineral Industries Extension Services, College of Mineral Industries, Pennsylvania State University.

Pétursson JG 1999. Skógræktaröldin, samanteknar tölur úr Ársriti Skógræktarfélags Ìslands [The First 100 Years of Tree Planting in Iceland]. Skógrcektarritid [Journal of the Icelandic Forest Association] 49-53. [In Icelandic with an English summary].

Port GR, Thompson JR 1980. Outbreaks of insect herbivores on plants along motorways in the United Kingdom. Journal of Applied Ecology 17, 649-656.

https://doi.org/10.2307/2402643

Rabe R, Keeb KH 1979. Enzyme activities and chlorophyl and protein content in plants as indicators of air pollution. Environmental Pollution 19, 119-137.

Rinn F 2003. Time series analysis and presentation for dendrochronology and related applications. Heidelberg.

Sienkiewicz-Paderewska D, Dmuchowski W, Baczeska AH, Bragoszewska P \& Gozdowski D 2017. The effect of salt stress on lime aphid abundance on Crimean linden (Tilia 'Euchlora') leaves. Urban Forestry \& Urban Greening 21, 74-79.

https://doi.org/10.1016/j.ufug.2016.11.010

Straw NA, Bladon FM, Day KR \& Fielding NJ 2019. The effects of high temperatures on individuals and populations of the green spruce aphid Elatobium abietinum (Walker). Agricultural and Forest Entomology (2019), 21, 69-78.

dx.doi.org/10.1111/afe.12304

Streeter R, Dugmore AJ, Lawson IT, Erlendsson E \& Edwards KJ 2015. The onset of the palaeoanthropocene in Iceland: Changes in complex natural systems. The Holocene 25(10), 1662-1675.

https://doi.org/10.1177/0959683615594468

The Environment Agency of Iceland 2018. Air Quality in Iceland. Source: https://www.ust. is/the-environment-agency-of-iceland/\#Tab2 (12.05.2018).

Villemant C 1981. Influence de la pollution atmospherique sur les populations d'aphides du pin sylvestre en foret de roumare (Seine- Maritime). Environmental Pollution (Series A), Ecological 
and Biological 24, 245- 262.

https://doi.org/10.1016/0143-1471(81)90063-5

Yoneyama T, Totsuka T, Hayakawa N \& Yazaki

J 1980. Absorption of atmospheric $\mathrm{NO}_{2}$ by plants and soils. V. Day and night $\mathrm{NO}_{2}$-fumigation effect on the plant growth and estimation of the amount of $\mathrm{NO}_{2}$ nitrogen absorbed by plants. Studies on effects of air pollutants on plants and mechanisms of phytotoxicity. Research Report of the National Institute for Environmental Studies 11, 31-50.

Zítková J, Hegrová J \& Andel P 2018. Bioindication of road salting impact on Norway spruce (Picea abies). Transportation Research Part D 59, 58-67. https://doi.org/10.1016/j.trd.2017.12.010

Manuscript received 26.10.2020

Accepted 14.4.2021 